\title{
Pyrrolidonyl Peptidase in Bacteria: A New Colrimetric Test for Differentiation of Enterobacteriaceae
}

\author{
By M. MULCZYK AND A. SZEWCZUK \\ Department of General Microbiology and Department of Biochemistry, \\ Institute of Immunology and Experimental Therapy, \\ Polish Academy of Sciences, Wroctaw, Poland \\ (Accepted for publication 27 November 1969) \\ SUMMARY
}

\begin{abstract}
A simple and rapid colorimetric test has been developed for the detection of pyrrolidonpl peptidase (PLP) activity in bacteria. Of 2354 strains belonging to various groups of enteric bacteria tested, 45I were PLP-positive. These included Citrobacter, 223 out of 226 strains, Klebsiella (178/188), Enterobacter (49/52), and one strain of Serratia.

Pyrrolidonyl peptidase was not detected in I I46 Shigella strains, 354 Salmonella strains, 333 Escherichia strains, 21 Arizona strains, nor in 33 strains of Proteus, Providencia and Hafnia.

In addition, 56 cultures of various Gram-negative and Gram-positive bacteria were tested for PLP. Enzyme activity was found in strains belonging to the genera Bacillus, Streptococcus, Staphylococcus, Micrococcus, Sarcina, Neisseria and Pseudomonas. The possibility of employing the PLP test for differentiation within the family Enterobacteriaceae is discussed.
\end{abstract}

\section{INTRODUCTION}

The classification of some bacteria may be based upon their peptidase activity (Muftic, 1965, I967; Muftic \& Schroder, I966; Westley et al. 1967). In a previous paper (Szewczuk \& Mulczyk, 1969) we reported new pyrrolidonyl naphthlyamides synthesized in our laboratory which could be used as chromogenic substrates for colorimetric determination of pyrrolidonyl peptidase activity. The enzyme was found in Gram-positive and Gram-negative bacteria. Pyrrolidonyl peptidase from Bacillus subtilis was purified and its properties and specificity were described.

This paper describes a simple colorimetric test for detection of pyrrolidonyl peptidase activity (PLP test) in bacteria and its adaptation as a new method for the differentiation of the various groups of Enterobacteriaceae.

\section{METHODS}

Reagents. (I) Substrate solution: o.or M-L-pyrrolidonyl- $\beta$-naphthylamide in methanol $(2.5 \mathrm{mg}$. $/ \mathrm{ml}$.). This substance was synthesized by the method previously described (Szewczuk \& Mulczyk, I969). (2) $0.5 \mathrm{M}$-tris/HCl buffer, pH 7.7. (3) 10\% (v/v) acetic acid solution in water. (4) $0.1 \%$ tetra-azotized $o$-dianisidine (Fast Blue B) solution in water.

Strains. A total of 2354 cultures that belonged to the various groups of Enterobacteriaceae were tested for PLP. The strains had been collected for several years 


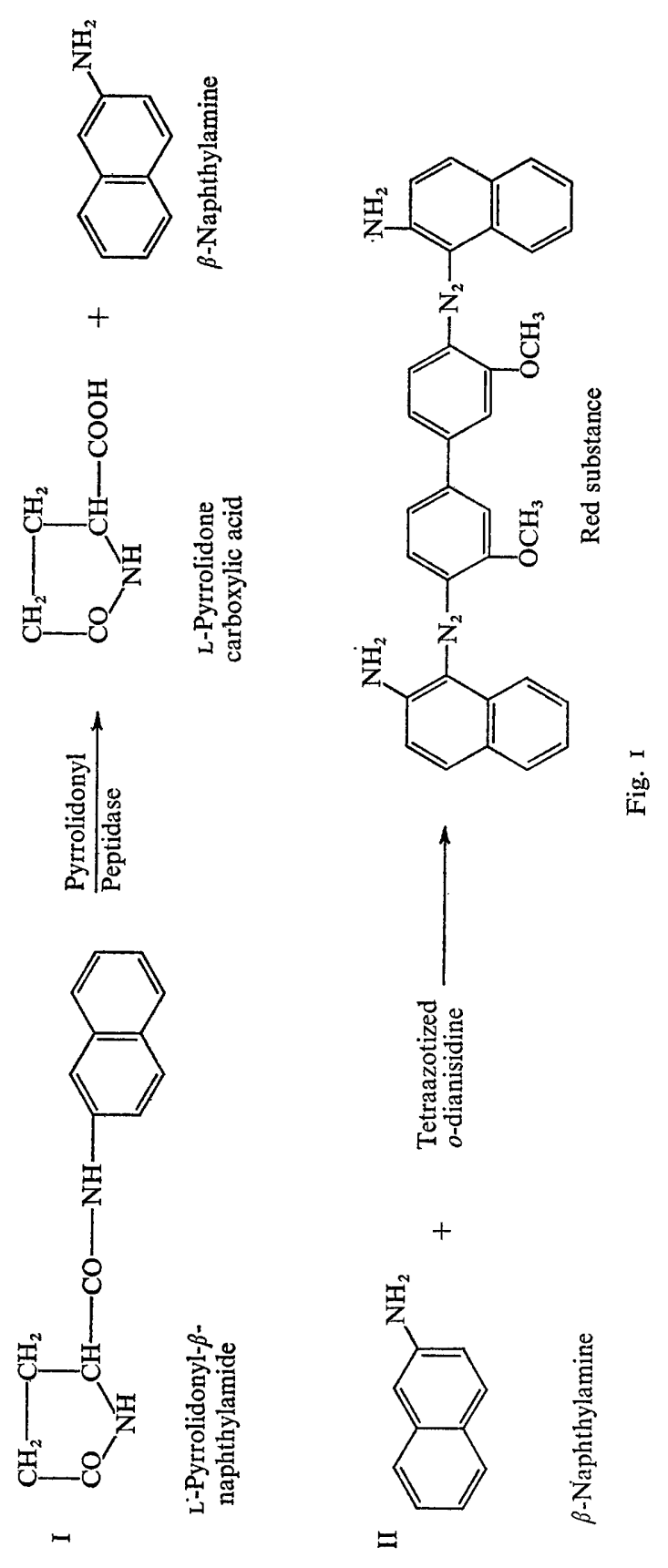


and had been received from different sources. Recently isolated strains from diagnostic material were also included. In addition, 56 strains of different groups of Gram-positive and Gram-negative bacteria were examined.

\section{Table I. The occurrence of PLP in enteric bacteria}

\section{Group}

Shigella dysenteriae, serotypes $\mathrm{I}-8$

$S$. flexneri, all serotypes

S. boydii, serotypes I-I5

S. sonnei

Salmonella typhi

$S$. paratyphi B

S. typhimurium

S. enteritidis

S. anatum

S. newington

S. heidelberg

$S$. brandenburg

$S$. morbificans

Escherichia,

O antigens I-I49

$\mathrm{H}$ antigens $\mathrm{I}-49$

$\mathrm{K}$ antigens $\mathrm{I}-9 \mathrm{I}$

From diagnostic material

Klebsiella aerogenes

$K$. pneumoniae

K. edwardsii var. edwardsii

$K$. edwardsii var. atlantae

$K$. ozaenae

$K$. rhinoscleromatis

K. oxytoca

Citrobacter,

$\mathrm{O}$ antigens $\mathrm{I}-32$

$O$ antigens $33-42$

From diagnostic material

Arizona, $\mathrm{O}$ antigens I-2 I

Enterobacter aerogenes

E. liquefaciens

E. cloacae

Proteus species

Providencia species

Hafnia species

Serratia species
Positive strains/tested strains

\begin{tabular}{|c|c|}
\hline Group & Genera \\
\hline $\begin{array}{l}0 / 34 \\
0 / 867 \\
0 / 45 \\
0 / 200\end{array}$ & o/1 I $46^{a}$ \\
\hline $\begin{array}{l}\text { o/76 } \\
\text { o/14 } \\
\text { o/67 } \\
\text { o/131 } \\
0 / 19 \\
0 / 20 \\
0 / 10 \\
0 / 2 \\
0 / 15\end{array}$ & $0 / 354^{b}$ \\
\hline $\begin{array}{l}0 / 143 \\
0 / 49 \\
0 / 91 \\
0 / 50\end{array}$ & $0 / 333^{c}$ \\
\hline $\begin{array}{l}60 / 61 \\
10 / 10 \\
19 / 20\end{array}$ & \\
\hline $\begin{array}{c}0 / 8 \\
28 / 28 \\
\text { I3/r3 } \\
48 / 48^{e}\end{array}$ & $\mathrm{I} 78 / \mathrm{I} 88^{d}$ \\
\hline $\begin{array}{l}87 / 88^{f} \\
10 / 10^{g}\end{array}$ & $223 / 226^{h}$ \\
\hline $\begin{array}{c}126 / 128 \\
0 / 21\end{array}$ & $0 / 2 \mathbf{I}^{h}$ \\
\hline $\begin{array}{c}34 / 35 \\
4 / 5\end{array}$ & $49 / 52^{i}$ \\
\hline $\begin{array}{r}11 / 12 \\
0 / 20 \\
0 / 10\end{array}$ & $\begin{array}{l}0 / 20 \\
0 / 10\end{array}$ \\
\hline $0 / 3$ & $0 / 3$ \\
\hline $\mathbf{I} / \mathbf{I}$ & $\begin{array}{c}I / I \\
45 I / 2354\end{array}$ \\
\hline
\end{tabular}

Notes

${ }^{a}$ Including strains from the Dysentery Reference Laboratory, London, and from Dr A. J. Weil, New York.

${ }^{b}$ Received from Professor Z. Buczowski, Gdańsk, and Professor J. Chomiczewski, Łódź.

- Including strains from Dr F. Ørskov, Copenhagen.

${ }^{a}$ Including Kauffmann's strains, received from Dr I. Ørskov, Copenhagen, and eight new serotypes (Maresz-Babczyszyn, 1962; Durlakowa et al. 1963).

${ }^{e}$ Received from Dr S. Kałuzewski, Warsaw.

$f$ Including NCDC strains.

${ }^{g}$ Sedlak \& Slajsova (1966).

${ }^{h}$ Received from Professor J. Sedlak, Prague.

${ }^{i}$ Received from Dr L. Le Minor, Paris. 
The pyrrolidonyl peptidase activity test (PLP test). This test is based on the following two reactions: pyrrolidonyl peptidase present in bacteria catalyses the hydrolysis of L-pyrrolidonyl- $\beta$-naphthylamide liberating free L-pyrrolidone carboxylic acid and $\beta$-naphthylamine (reaction I). The latter substance, after coupling with tetraazotized $o$-dianisidine (Fast Blue B), gives the red azo substance (reaction II) (Fig. I).

Procedure. The culture to be tested is inoculated on to an agar slant and incubated for $\mathrm{I} 8$ to $24 \mathrm{hr}$ at $37^{\circ}$. The bacteria are washed off with $\mathrm{I} \cdot 5 \mathrm{ml}$. saline and $0.4 \mathrm{ml}$. suspension is added to a test-tube. Then $0.05 \mathrm{ml} .0 .5-\mathrm{M}$ tris $/ \mathrm{HCl}$ buffer and $0.05 \mathrm{ml}$. substrate (L-pyrrolidonyl- $\beta$-naphthylamide) are added and mixed immediately. The suspension is incubated in a water bath at $37^{\circ}$ for $3 \mathrm{hr}$ and then $0.2 \mathrm{ml}$. of acetic acid is added. The colour is developed by addition of $0.1 \mathrm{ml}$. Fast Blue solution followed by incubation at $37^{\circ}$ in a water bath for $\mathrm{I} \mathrm{hr}$. A positive reaction is indicated by a strong red colour of the suspension, stable for at least one day at room temperature.

\section{RESULTS}

The PLP activities of 2354 cultures from various groups of Enterobacteriaceae are presented in Table r. It can be seen that Shigella, Salmonella, Escherichia, Arizona, Proteus, Providence and Hafnia species gave a uniformly negative result in PLP test. In contrast, Klebsiella species gave a positive result except for all strains of $K$. edwardsii var. atlantae tested and one strain each of $K$. aerogenes and $K$. edwardsii var. edwardsii. With few exceptions (see Table I) Citrobacter and Enterobacter strains were also positive. The one Serratia strain tested gave a positive result.

In addition to the above-mentioned cultures of Enterobacteriaceae, 56 Grampositive and Gram-negative strains were examined for PLP. The results are recorded in Table 2: except for the strains belonging to the genera Corynebacterium and Saccharomyces, strains that gave positive reactions were found in all remaining groups tested.

Table 2. The occurrence of PLP in some Gram-positive and Gram-negative bacteria*

\begin{tabular}{lcc}
\multicolumn{1}{c}{ Genus } & $\begin{array}{c}\text { No. of cultures } \\
\text { tested }\end{array}$ & PLP-positive \\
Pseudomonas & 8 & 4 \\
Neisseria & 4 & 4 \\
Micrococcus & I & I \\
Bacillus & 9 & 8 \\
Corynebacterium & 3 & 0 \\
Streptococcus & 7 & 5 \\
Sarcina & 3 & 3 \\
Staphylococcus & 19 & 16 \\
Saccharomyces & 2 & 0
\end{tabular}

* Strains from Polish Collection of Micro-organisms, Wrockaw, and from diagnostic material.

\section{DISCUSSION}

Different biochemical tests have been described that have distinct taxonomic value within the family of Enterobacteriaceae. Some tests may be readily applied in laboratory diagnosis and were found useful in the differentiation of enteric bacteria (Edwards \& Ewing, 1962; Cowan \& Steel, 1965). Our data indicate that the simple test for detection of pyrrolidonyl peptidase activity in bacteria described in this paper may 
be considered as an additional one in the classification and differentiation of bacteria. This is supported by the fact that the cultures of some species had PLP and the others were devoid of the enzyme. Thus the PLP test may be applied in the differentiation of strains which still constitute diagnostic problems. These are strains that are closely related biochemically and serologically and that compose the Salmonella-ArizonaCitrobacter division. Since the great majority of Citrobacter strains are positive in the PLP test and those of Salmonella and Arizona are negative, the introduction of the test may be of great value in the differentiation of these organisms in addition to the tests for lysine decarboxylase (Møller, 1955) and KCN tolerance (Møller, 1954).

The lack of PLP in all eight strains of Klebsiella edwardsii var. atlantae should also be noted. However, only further studies of a larger number of Klebsiella cultures can show whether negative strains in the PLP test are limited to the subgroup of $K$. edwardsii var. atlantae.

Considering that the number of strains of some species that were tested was small, no attempts were made to evaluate the usefulness of the PLP test in routine diagnostic work. To do so, further studies are required on a larger number of strains of different serotypes of Enterobacteriaceae including original stock cultures and those isolated from diagnostic material. These studies are now in progress in our laboratory and the results will be the subject of a separate communication. It must be stressed here, however, that as the distribution of pyrrolidonyl peptidase is characteristic as a rule of the individual bacterial groups, the PLP test may be of great diagnostic value in differentiation within the family of Enterobacteriaceae.

\section{REFERENCES}

Cowan, S. T. \& STEel, K. J. (1965). Manual for the Identification of Medical Bacteria. Cambridge University Press.

Durlakowa, I., Maresz-Babczyszyn, J., Przondo-Hessek, A. \& Lachowicz, Z. (1963). New Kantigenic types of bacilli of the genus Klebsiella. Archivum Immunologiae et Therapiae Experimentalis II, 549.

EDWARDs, P. R. \& EWING, W. H. (1962). Identification of Enterobacteriaceae, 2nd ed. Minnesota: Burgess Publishing Co.

MARESZ-BABCZYSZYN, J. (1962). New antigenic types of Klebsiella bacilli. Archivum Immunologiae et Therapiae Experimentalis ro, 589.

MøLler, V. (1954). Diagnostic use of the Braun KCN test within the Enterobacteriaceae. Acta Pathologica et Microbiologica Scandinavica 34, 115.

MøLleR, V. (1955). Simplified tests for some amino acid decarboxylases and for the arginine dihydrolase system. Acta Pathologica et Microbiologica Scandinavica 36, 158.

MuFTIC, M. (1965). Classification of Mycobacteria by their peptidase action on various amino acid naphthylamides. Praxis der Pneumologie 19, 33. (In German.)

MuFTIC, M. (1967). Application of chromogenic substrate to the determination of peptidases in Mycobacteria. Folia microbiologica, Prague I2, 500.

Muftic, M. \& SCHroder, E. (I966). Peptidasegram in the differentiation of Bacilli species. Pathologia et Microbiologia 29, 252.

Sedlak, J. \& Slajsova, M. (I966). Antigen structure and antigen relations of the species Citrobacter. Zentralblatt für Bakteriologie, Parasitenkunde, Infektionskrankheiten und Hygiene (Abteilung I) 200, 369. (In German.)

SzewCZuK, A. \& MULCZYK, M. (1969). Pyrrolidonyl peptidase in bacteria. The enzyme from Bacillus subtilis. European Journal of Biochemistry 8, 63.

Westley, J. W., Anderson, P. J., Close, V. P., Halpern, B. \& Lederberg, E. M. (1967). Aminopeptidase profiles of various bacteria. Applied Microbiology 15, 822. 